as regards his facts. $\mathrm{He}$ appears to have overlooked the observations proving the lower salinity of inter-tropical water, which I had cited as furnishing an additional indication that Polar water is constantly rising from the bottom towards the surface in the equatorial area. These observations have been most remarkably confirmed by those taken by the physicists of the Challenger. For, whilst in the extra-tropical area the sp. gr. of surface-water was in excess of that of bottom-water, in the equatorial area it was reduced to an almost precise correspondence with it, due allowance for temperature being of course made.

According to Mr. Croll's doctrine, the whole of that vast mass of water in the North Atlantic, averaging, say, I,500 fathoms in thickness, and 3,600 miles in breadth, the temperature of which (from $40^{\circ}$ downwards) as ascertained by the Challenger soundings, clearly shows it to be mainly derived from a Polar source, is nothing else than the reflux of the Gulf Stream. Now, even if we suppose that the whole of this stream, as it passes Sandy Hook, were to go on into the closed Arctic Basin, it would only force out an equivalent body of water. And as, on comparing the sectional areas of the two, I find that of the Gulf Stream to be about 1 -gooth that of the North Atlantic underflow ; and as it is admitted that a large part of the Gulf Stream returns into the MidAtlantic circulation, only a branch of it going on to the north-east; the extreme improbability (may I not say impossibility?) that so vast a mass of water can be put in motion by what is by comparison such a mere rivulet - the north-east motion of which, as a distinct current, has not been traced eastward of $30^{\circ} \mathrm{W}$. long.--seems still more obvious.

Lastly, the Challenger observations in the South Atlantic have proved exactly what I had anticipated, viz., that the bottom-temperature is lower, and that the Polar underflow lies much nearer the surface in this ocean than in the North Atlantic. Now this case appears to me to afford the experimentum crucis between Mr. Croll's doctrine and my own. For my prediction of this result was based on the fact, that, as there is here a perfectly open communication between the Polar and equatorial areas, the vertical circulation would take place more freely. On the other hand, according to Mr. Croll's doctrine, it would have been expected that there should be a far smaller reflux, or no reflux at all. For, though a portion of the equatorial current passes southwards when it meets the coast of South America, there is no ground whatever for believing that it ever goes near the Antarctic circle; and if it did find its way thither, there is no "closed basin" from which it can drive back a return current.

As it is usually considered in scientific inquiry that the verification of a prediction affords cogent evidence of the validity of the hypothesis on which it is based, I.venture to submit that so far my case has been made good.

William B. CARPENTER

\section{THE DEATH OF DR. LIVINGSTONE}

TH

$\mathrm{E}$ daily papers have obtained from the London office of the New York Herald the following telegram, containing details of the death of Dr. Livingstone, dated Suez, Sunday, March 29 :-

"The Malvea arrived off Suez at eleven on Saturday night, having Mr. Arthur Laing and Jacob Wainwright on board, with the body of Livingstone. He had been ill with chronic dysentery for several months past. Although well supplied with stores and medicine, he seems to have had a presentiment that the attack would prove fatal. He rode a donkey, but was subsequently carried, and thus arriyed at Muilala, beyond Lake Bemba, in Bisa country, when he said, "Build me a hut to die in.' The hut was built by his followers, who first made him a bed. He suffered greatly, groaning night and day. On the third day he said, "I am very cold ; put more grass over the hut.' His followers did not speak or go near him. Kitumbo, Chief of Bisa, sent flour and beans, and behaved well to the party. On the fourth day Livingstone became insensible, and died about midnight. Majuahra, his servant, was present. His last entry in diary was on April 27. He spoke much and sadly of home and family. When first seized he told his followers he intended to change everything for ivory, to give to them, and to push on to Ujiji and Zanzibar, and try to reach England. On the day of his death the followers consulted what to do. The Nassick boys determined to preserve the remains. They were afraid to inform the Chief of Livingstone's death. The secretary removed the body to another hut, around which he built a high fence to ensure privacy. They opened the body and removed the internals, which were placed in a tin box and burned inside the fence under a large tree. Jacob Wainwright cut an inscription on the tree as follows:- "Dr. Livingstone died on May 4, 1873,' and superscribed the name of the head man Susa. The body was preserved in salt, and dried in the sun for twelve days. Kitumbo was then informed of the death, and beat drums and fired guns as a token of respect, and allowed the followers to remove the body, which was placed in a coffin formed of bark, then journeyed to Unyanyembe about six months, sending an advanced party with information addressed to Livingstone's son, which met Cameron. The latter sent back a bale of cloth and powder. The body arrived at Unyanyembe ten days after advanced party, and rested there a fortnight. Cameron, Murphy, and Dillon together there. Latter very ill, blind, and mind affected. Committed suicide at Kasakera; buried there. Here Livingstone's remains were put in another bark case, smaller, done up as a bale to deceive natives who objected to the passage of the corpse, which was thus carried to Zanzibar. Livingstone's clothing, papers, and irstruments accompany the body. When ill Livingstone prayed much. At Muilala he said, 'I am going home.' Chumah remains at Zanzibar. Webb, American consul at Zanzibar, is on his way home, and has letters handed to him by Murphy from Livingstone for Stanley, which he will deliver personally only. Geographical news follows. After Stanley's departure the Doctor left Unyanyembe, rounded the south end of Lake Tanganyika, and travelled south of Lake Bemba, or Bangneoleo, crossed it south to north, then along east side, returning north through marshes to Muilala. All papers sealed. Address Secretary of State, in charge of Arthur Laing, a British merchant from Zanzibar. Murphy and Cameron remain behind."

These details are few but intensely touching. We believe that the Peninsular and Oriental Company's Bombay steamer Malzera, with Dr. Livingstone's body on board, is due on April I 3 at Southampton. The body will be landed at that port and conveyed to London, by railway, for interment in Westminster Abbey; it is to be regretted that the faithful Chumah does not accompany his master's remains. It is impossible that Government will fail in doing what the whole civilised world takes for granted it will do-pay all possible honour to the remains of H. M. Consul, and of probably the greatest traveller that this or any other country ever produced.

REPORT OF PROF. FARKER'S HUNTERIAN

\section{LECTURES "ON THE STRUCTURE AND DEVELOPMENT OF THE VERTEBRATE SKULL"}

THE new Hunterian Professor, Mr. W. Kitchen Parker, has just completed his course of eighteen lectures at the College of Surgeons, embodying in them the results of his researches on that most difficult problem, the deve- 